\title{
Realistyczny neokantyzm Aloisa Riehla w interpretacji Jana Stepy
}

DOI: http://dx.doi.org/10.12775/RF.2016.005

Jan Piotr Stepa (1892-1959) żył na przełomie dziewiętnastego i dwudziestego wieku. Urodził się w Sassowie, miejscowości leżącej obecnie na terytorium Ukrainy. Podjął naukę w szkole w Złoczowie, a następnie studia teologiczne we Lwowie. W roku 1915 przy udziale arcybiskupa Józefa Bilczewskiego przyjął święcenia kapłańskie. Kilka lat później, w 1918 roku, został osadzony w więzieniu pod zarzutem działalności antyukraińskiej. Więzienie opuścił w 1919 roku. W 1921 objął posadę księdza wikariusza w parafii Marii Magdaleny we Lwowie, by rok później (1922), między innymi pod naukową opieką Désiré Merciera, podjacć studia filozoficzne na Université Catholique w belgijskim Louvain, gdzie w 1925 roku otrzymał stopień doktora filozofii. W 1927 roku objął Katedrę Filozofii Chrześcijańskiej na Uniwersytecie Jana Kazimierza we Lwowie, zajmując miejsce księdza Kazimierza Waisa. 21 czerwca 1929 roku, cztery lata po obronie doktoratu, Stepa uzyskał habilitację, następnie 1 września 1932 roku został nominowany na profesora nadzwyczajnego swojej Alma Mater, by z otrzymaną desygnacją naukową pracować na tej uczelni, aż do momentu jej zamknięcia (1939 r.). Kolokwium habilitacyjne Stepy odbyło się na podstawie, opublikowanej w 1927 roku, rozprawy Neokantowskie próby realizmu a neotomizm ${ }^{1}$.

Tytuł książki wskazuje na zainteresowanie lwowskiego teologa i filozofa problematyką neokantowską. Znaczny fragment przytoczonej pracy (ujęty w części I), poświęcony jest krytycznej deskrypcji systemu

1 Zob. A. Nowak, Słownik biograficzny kapłanów diecezji tarnowskiej 1786-1985, t. 1, Biskupi i kanonicy, Wydawnictwo Diecezji Tarnowskiej, Tarnów 1999. Por. www.ipsb. nina.gov.pl/index.php/a/jan-piotr-stepa. 
Aloisa Riehla (1844-1924). Myśl austriackiego neokantysty jest na gruncie filozofii polskiej, wyłączając nieliczne grono badaczy a zarazem sympatyków ruchu neokantowskiego, zajmujących się na co dzień historią neokantyzmu, zapoznana. Fakt ten stał się przyczynkiem do napisania artykułu będącego próbą przybliżenia, zaproponowanej przez galicyjskiego myśliciela i orędownika chrześcijańskiej szkoły filozofii lwowskiej, wykładni filozoficznego programu Riehla.

Zanim Stepa skieruje swoją refleksję na tory ad finem merytorycznej analizy filozoficznego projektu Riehla, precyzuje pojęcie: neokantyzm. Kreśli krótką linię genealogiczną kształtowania się tego filozoficznego nurtu. Dopuszcza powszechnie uznawane założenie, w myśl którego neokantyści, to filozofowie działający według nośnego postulatu powrotu do nauki Kanta wyrażonego dewizą: „Also muß auf Kant zurückgegangen werden", która wiąże zerwaną więź filozofii i nauki². Stepa akcentuje również historycznie uznawany fakt: zwrot w stronę filozofii Kanta intelektualnie aranżuje okres działania - badających system Kanta - filologów. Grupę tę stanowią między innymi: Rudolf Reicke, Benno Erdmann i Albrecht Krause.

Z czasem aktywność kantowskich filologów staje się przyczynkiem powstania obozu myśli neokantowskiej. W 1832 roku działanie tej grupy naukowców/humanistów zapoczątkowuje Karl Fortlage, także Friedrich Eduard Beneke, Ernst Reinhold, Karl Alexander von Reichlin-Meldegg, Christian Hermann Weisse, Karl von Prantl, Carl von Rokitański, Jan Müller, Adolf Eugen Fick oraz Hermann von Helmholtz. Wśród inicjatorów ruchu neokantowskiego Stepa wymienia również Eduarda Zellera, Kuno Fischera, Friedricha Alberta Langego, Moritza Wilhelma Drobischa, Ottona Liebmanna, a także Hermanna Cohena i Paula Natorpa założycieli szkoły marburskiej³.

Neokantyzm staje się szkołą filozoficzna, a zarazem czymś więcej: filozoficznym ruchem zapoczątkowanym jeszcze w latach pięćdziesiątych XIX wieku; szerokim intelektualnym frontem, którego prężny rozwój przypada na lata 1870-1914. Jego niejednoznaczny charakter wznosi

2 „Die Rückkehr zu Kant ist in Wahrheit einem Fortschritt gleich zu achten. Die Fäden wurden wieder angeknüpft, welche Wissenschaft und Philosophie zu wechselseitigen Nutzen verbinden und nur zeitweilig von der Naturphilosophie durchschnitten worden waren. Auch sollte das Losungwort: Zurück zu Kant! kein Stehenbleiben bei Kant bedeuten; denn auch die Wissenschaft seit Kant ist nicht stehen gebleiben". O. Liebmann, Kant und die Epigonen, Stuttgart C. Schober, Stuttgart 1865. Zob. A. Riehl, Der Philosophische Kritizismus. Geschichte und System. Geschichte des Philosophischen Kritizismus, Bd. 1, Verlag von Wilhelm Engelmann, Leipzig 1908, s. 8-9. Zob. A. Noras, Historia neokantyzmu, Wydawnictwo Uniwersytetu Śląskiego, Katowice 2012, s. 410.

3 Por. J. Stepa, Neokantowskie próby realizmu a neotomizm, Bibljoteka Religijna, Lwów 1927, s. 10. 
falę różnorodnych gradacji, grupowań i kategoryzacji w ramach tradycji neokantyzmu.

Cenną klasyfikację neokantyzmu wprowadza według Stepy Friedrich Überweg, który wyróżnia w ramach neokantyzmu 7 kierunków: fizjologiczny (Helmholtz i Lange), metafizyczny (Liebmann i Volkelt), realistyczny (Riehl, Külpe), logicystyczny (Cohen, Natorp, Cassirer), teoretyczny krytycyzm wartości (Windelband, Rickert, Münstenberg), przekształcenie relatywistyczne krytycyzmu (Simmel) oraz teologiczną systematykę (Albrecht Ritschl) ${ }^{4}$. Całościowo neokantyzm niezwykle trudno zdefiniować, gdyż różnie rozumiana jest jego istota, z czego Stepa zdaje sobie sprawę.

Naukową ambicją polskiego filozofa nie jest bezpośrednie rozstrzyganie o wartości poszczególnych odłamów odradzającej się myśli Immanuela Kanta, ani też przybliżanie historycznego tła neokantyzmu poprzez rozdrabnianie się $\mathrm{w}$ kantowskim i pokantowskim nazewnictwie. Zadaniem, które stawia sobie Stepa, jest potwierdzenie tezy, w myśl której koncepcja filozofii Riehla jest formą realizmu krytycznego. Stepa poświadcza swoje stanowisko skromnym, systematycznym wykładem filozoficznego credo, z wyraźnym uwydatnieniem idei przewodniej Riehlowskiego realizmu jako krytycznego monizmu.

Próbie samodzielnego opisu architektoniki myślenia autora Realistische Grundzüge..., służy płaszczyzna epistemologiczna, która będąc punktem wyjścia filozoficznych analiz, powinna otwierać drzwi jej formie właściwej - filozofii pierwszej: metafizyce ${ }^{5}$.

Riehl wykazując niemożliwość naukowego systemu metafizyki, broni Kantowskiego stanowiska negującego wartość spekulacji metafizycznej; kwestionuje wartość metafizyki, która jako dziedzina wychodząca poza możliwości empirycznego określenia i poza granice doświadczenia, wznosi się również ponad ludzkie możliwości poznania. Taka metafizyka, o czym - powołując się na Kanta - informuje Stepa, „jest bezbrzeżnym morzem, gdzie żaden krok naprzód nie pozostawia śladu, a na horyzoncie nie widać żadnego celu [...]. Dlatego w takiej sytuacji, pierwszym i najważniejszym pytaniem filozofa jest pytanie o to: co właściwie rozum chce osiągnąć za pomocą metafizyki? [Jaki jest cel metafizyki - A.M]. Można określić metafizykę dziedziną wznoszącą się za pomocą rozumu od poznania tego, co zmysłowe, do poznania tego, co nadzmysłowe ${ }^{\prime \prime}$. Zapamiętać jednak należy, że metafizyczne hipotezy

4 F. Überweg, Grundriss der Geschichte der Philosophie vom Beginn des XX Jahrhunderts bis auf die Gegenwart, hrsg. V. K. Österreich, Berlin 1916, s. 364-365.

5 A. Riehl, Zur Einführung in die Philosophie der Gegenwart. Acht Vorträge, B.G. Teubuer, Leipzig 1908, s. 3.

${ }^{6}$ I. Kant, O postępach metafizyki. tłum. A. Banaszkiewicz, Wydawnictwo słowo/ /obraz terytoria, Gdańsk 2007, s. 16-17. 
nie stanowią pożywki dla intelektu/rozsądku, ograniczając się wyłącznie do roli otumaniającego opium, stąd płynność i nietrwałość stawianych przez metafizykę twierdzeń, rodzi jedynie pozór wiedzy ${ }^{7}$. Metafizyka jest możliwa wyłącznie jako dyscyplina negatywna lub krytyczna. "Jako taka, jest ona teorią pojęć granicznych doświadczenia [...]; ona wyznacza granice przedstawienia, które przedstawienie wprawdzie osiąga, ale poza nimi niczego nie ujmuje" ${ }^{\prime \prime}$.

Stepa uwzględniając perspektywę epistemologiczną i metafizyczna, stawia pytania o możliwość poznania tego, co poza nami (poza poznającym) oraz o sposobność mocnej argumentacji na rzecz prawomocności takiego poznania. Teoria poznania chcąc przejąć rolę punktu źródłowego filozofii, wymaga jednak według tarnowskiego kapłana rzetelnego opracowania, by móc „bez obawy omyłki stąpać po szerokim i niebezpiecznym polu wszelkich spekulacji filozoficznych", a w razie orzeczenia kruchości epistemologicznych fundamentów realizmu, wkroczyć na nową drogę filozoficznych dociekań.

Opracowując program filozofii Aloisa Riehla, teolog sięga po założenia szkoły würzburskiej, wyłożone w filozoficznym programie jej fundatora Oswalda Külpego i Augusta Messera ${ }^{10}$. Nauki tej szkoły Stepa nazywa "syntezą kierunków [realistycznych i idealistycznych - A.M.], ergo intelektualne wysiłki Riehla, a także Cohena służą [jego zdaniem A.M.] za pomost w stworzeniu neokantowskiej syntezy realistycznej"11. Ideowe założenia Würzburga mają charakter pośredni. Są osadzone w psychologii Külpego; w jego krytyczno-psychologicznym realizmie uznającym wartość zarówno zmysłowego jak i umysłowego źródła poznania. Dlatego filozoficzny projekt tej eksperymentalno-psychologicznej szkoły Stepa poróżnia z ortodoksją Riehlowskiego stanowiska ${ }^{12}$.

Alois Riehl - zwolennik czucia, zmysłowego aspektu w procesie poznawania rzeczywistości - opowiada się po stronie empiryzmu, podkreśla niekonieczność myślenia nazywając myślenie czynnością wyłącznie formalna, bez której w gruncie rzeczy można się w procesie poznania obejść. Tym samym honoruje przeświadczenie, wedle którego w filozofii poznawany przedmiot wymaga jako warunku sine qua non pola em-

7 J. Stepa, Neokantowskie próby realizmu..., op. cit., s. 20-21.

8 A. Riehl, Über wissenschaftliche und nichtwissenschaftliche Philosophie, w: Philosophische Studien aus vier Jahrzehnten, Verlag von Wilhelm Engelmann, Leipzig 1925, s. 248-249. Zob. A. Noras, Historia neokantyzmu..., s. 426.

9 J. Stepa, Neokantowskie próby realizmu..., op. cit., s. 13.

10 Zob. A. Noras, Historia neokantyzmu..., op. cit., s. 424, 427, 429.

11 J. Stepa, Neokantowskie próby realizmu..., op. cit., s. 15-16.

12 W. Moog, Die deutsche Philosophie des 20. Jahrhunderts in ihren Grundproblemen, Verlag von Ferdinand Enke, Stuttgart 1922, s. 130. Zob. A. Noras, Historia neokantyzmu..., s. 431. 
pirycznego, natomiast każda nadempiryczna, zwłaszcza metafizyczna hipoteza staje się jedynie skazą zniekształcającą proces poznania ${ }^{13}$.

Swojego przekonania Riehl broni w dziele Der philosophische Kritizismus..., w którym nazywa filozofię zarazem nauką i krytyką poznania. Poznanie, o którym traktuje filozofia jest jak sądzi, poznaniem naukowym, to znaczy próbą rozważenia problemu wiedzy, poprzez określenie jej wartości oraz wyznaczenie roli i znaczenia stanowiących ją założeń. Dodaje, iż filozofia, by nie dać się uwieść próżnej spekulacji i tym samym nie stracić na swej wartości, powinna utrzymywać ścisły związek z obszarem nauk szczegółowych. Jednocześnie każdy reprezentant nauk szczegółowych powinien pamiętać, by bezładnie skumulowane, sprawdzone fakty doświadczenia wiązać w syntetycznie uporządkowaną całość, zgodnie z planem budowy gmachu wiedzy. Jej architektem powinno być - wtrąca Stepa - a priori myślenia ${ }^{14}$.

Wykazaną współzależność filozofii i przyrodoznawstwa Riehl oddaje słowami:

Żaden przyrodnik nie powinien przestąpić progu laboratorium lub sali wykładowej, jeśli nie przestudiował należycie filozofii, która mu ułatwi zrozumienie wartości pracy naukowej i jej metod. Przyszłość naukowej filozofii zależy od podniesienia wiedzy do poziomu filozofii [...]. Podniesienie wiedzy na wyżyny filozofii jest współczesnym zadaniem filozofii, najwyższym i najobszerniejszym zadaniem, które może być kiedykolwiek postawione $\mathrm{w}$ dziedzinie poznania ${ }^{15}$.

Cytowana deklaracja nie tylko pozwala zorientować się $\mathrm{w}$ temacie żywionego przez Riehla apologetycznego stosunku do filozofii, jej roli i znaczenia w systemie świata, ale także przystaje na zmienność rozstrzygnięć filozofii, którą transformuje czas zapowiadając niestałość zapatrywań na poszczególne problemy filozoficzne. W ten sposób filozofia potwierdza swoją niejednowymiarowość i dynamizm. Następstwem tego dynamizmu jest umiejętność wyjścia poza ograniczenia pojedynczej nauki szczegółowej. Filozofia odkrywa przed człowiekiem spectrum możliwości, preferencji; implikuje różnorodność, mnogość i wielokierunkowość. Filozofia „daje człowiekowi światopogląd, wznoszący go ponad ograniczony widnokrąg poszczególnych nauk, które wpatrzone w swój przedmiot nie widzą przed sobą szerszych horyzontów. Filozofia

13 Zob. Riehl A.: Der Philosophische Kritizismus und seine Bedeutung für die positive Wissenschaft. Bd. 2. Teil 1: Die sinnlichen und logischen Grundlagen der Erkenntniss, Verlag von Wilhelm Engelmann, Leipzig 1879, s. 87.

14 Zob. J. Stepa, Neokantowskie próby realizmu..., op. cit., s. 19.

15 A. Riehl, Zur Einführung in die Philosophie der Gegenwart. Acht Vorträge, B.G. Teubner, Leipzig 1903, s. 238-242. A. Riehl, Der Philosophische Kritizismus und seine Bedeutung für die positive Wissenschaft..., s. 120. Zob. J. Stepa, Neokantowskie próby realizmu..., s. 20 . 
powinna podnosić człowieka"16, a zatem być umiejętnością spoglądania na problem z perspektywy uwzględniającej alternację i zmianę, która aproksymuje elementy dalekie i uznane wcześniej za niepoznawalne, czyniąc je bliskimi, poznawalnymi i pozwalającymi przyjąć określoną postawę.

Dociekania mające na celu określenie statusu filozofii jako krytyki poznania, wymagają jednak ustalenia terminus a quo poznawczego procesu. Riehl czyni tym źródłowym momentem poznania, świadomość jako pierwotną daną poprzedzającą wtórną - jego zdaniem - relację podmiot-przedmiot, której Kant niesłusznie nadaje status krytycznego punktu wyjścia. Riehl, neguje pierwotną funkcję dualistycznego stosunku podmiot-przedmiot, zarzucając autorowi Kritik der reinen Vernunft nieświadome uwikłanie się $\mathrm{w}$ dogmatyzm, odnotowując istotne spostrzeżenie: „to właśnie było wielkim błędem Kanta, że zwalczając dogmatyzm w poznaniu, sam stanął na jego platformie, gdyż przyjął bez wszelkich dowodów istnienie form poznania jako fakt niezaprzeczony"17.

Bezkrytyczne uznanie przez Kanta relacji podmiot-przedmiot, każe Riehlowi wyszukać innego, nowego początku poznawczego procesu fundującego niejako, ową wtórną relację. Tym początkiem Riehl mianuje świadomość jako proces: czysta, absolutną funkcję nie będącą transcendentalną świadomością w ogóle (Bewußtsein überhaupt), lecz świadomością jako organiczno-życiowym zjawiskiem, zjawiskiem bytu. Ta świadomość to biologiczna służebnica życia; to psycho-fizyczna świadomość czucia będąca źródłem delimitacji, łączącym w sobie to, co podmiotowe, w-podmiotowe, wewnętrzne (immanentne) z tym, co wypływające z podmiotu, od-podmiotowe i oddziałujące na to, co poza podmiotem; to, co zewnętrzne (transcendentne); to świadomość jako nie-myślowa forma działania bez działającego i czynność bez przyczyny ${ }^{18}$.

Praca świadomości nie akcentującej myślenia (cogito), lecz czucie (sentio) wiąże się z swoistym, Riehlowskim ujęciem stosunku ja i nie-ja (Ego i Non-ego) wypowiedzianym w słowach: czuję, dlatego uważam, że jest (sentio ergo sum et est). Świat przedmiotowy musi istnieć, gdyż czuję i posiadam wrażenia ${ }^{19}$. Ego implikuje Non-ego. Odczucie własnego ja, wymaga współodczuwania pierwiastka nie-ja jako tego, co istnieje poza

16 A. Riehl, Zur Einführung in die Philosophie der Gegenwart. Acht Vorträge..., s. 21-24 .

17 J. Stepa, Neokantowskie próby realizmu..., op. cit., s. 22.

18 A. Riehl, Über Begriff und Form der Philosophie, Duncker, Berlin 1872, s. 41. Por. J. Stepa, Neokantowskie próby realizmu..., op. cit., s. 23. Por. I. Kant, Krytyka czystego rozumu, przeł. R. Ingarden, Kęty 2001, s. 202-203.

19 Zob. B. Trochimska-Kubacka, Neokantyzm, Wydawnictwo Uniwersytetu Śląskiego, Wrocław 1997, s. 23. 
ja/niezależnie od ja ${ }^{20}$. Dlatego Riehlowska „świadomość, to nie nasze cogito, lecz sentio, a zatem to świadomość połączona z czuciem. [O ile A.M.] cogito popiera tylko stanowisko podmiotu/Ja, [o tyle - A.M.] sentio także przedmiotowi/nie-Ja daje równouprawnienie w świadomości" ${ }^{21}$. Z tego powodu, w procesie wyznaczania filozoficznego źródła poznania, intelekt i jego kategorie, zgodnie z Riehlowskim poglądem o realności świata, ustępują miejsca formie poznania zmysłowego, korespondującego z poznawczą kategorią czucia. Nadanie priorytetowego charakteru poznaniu zmysłowemu przewartościowuje również sferę sądów.

Riehl przesuwa akcent pewności poznania z sądu pojęciowego, jako myślowej spekulacji, na sąd zmysłowy. Utrzymuje pewność poznania na - czuciowym, materialnym - sądzie zmysłowym; sądzie nie będącym wynikiem myślenia, lecz sensualnego czucia (sentio) jako poznania zmysłowego ${ }^{22}$. Utrzymuje, iż sąd ten jako supozycja w sensie właściwym, pozwala rozróżnić przedmiot poznania od tego, co zostaje ujęte jedynie $\mathrm{w}$ formę myślowej spekulacji; sąd czucia, to sąd zmysłowy, zwany również sądem spostrzeżeniowym, wypracowany dzięki sile wrażenia. Sąd zmysłowy jako swoisty trybunał, nie tylko pozwala pojąć myślowo poznawaną rzecz, ale w pierwszej kolejności również spostrzec i rozpoznać ją jako konkretną i zewnętrzną. Rozpoznanie to dokonuje się za sprawą siły czucia i dążenia woli. Zarówno świadomość czucia, jak i siła woli pozwalają więc wytworzyć sąd o istnieniu i realności przedstawionej rzeczy.

O ile sąd zmysłowy decyduje o każdej formie orzekania pojęciowego, o tyle sąd pojęciowy nie jest sądem we właściwym sensie, lecz jest tylko pewną kombinacją pojęć logiczno-matematycznej prawdy, nie wychodzącą poza obszar apriorycznej myśli, którego zgodność z rzeczywistością jest niepotwierdzona; tak rozumiany sąd pojęciowy to wyłącznie koncept problematyczny, o pewności wyłącznie formalnej, łączącej jedynie te pojęcia, które wchodzą z sobą w konieczny i ogólny stosunek.

Riehl przesuwa zatem akcent pewności poznania $\mathrm{z}$ myślenia na czucie i wynikający z aktu czucia rzeczy zewnętrznej, sąd zewnętrzny/ spostrzeżeniowy ${ }^{23}$. Dodaje, iż rzeczy zewnętrzne interferują w stosunku koegzystencji albo w akcie sukcesji. To związki dwojakiego rodzaju: o ile stosunek koegzystencji (Coexistenz) konotuje równoczesność lub współistność rzeczy i w tym znaczeniu koegzystencja zostaje ujęta w formę

20 A. Riehl, Über Begriff und Form der Philosophie. Eine allgemeine Einleitung in das Studium der Philosophie, Duncker, Berlin 1872, s. 41. Zob. J. Stepa, Neokantowskie próby realizmu..., op. cit., s. 22-24.

21 J. Stepa, Neokantowskie próby realizmu..., op. cit., s. 28.

22 A. Riehl, Der Philosophische Kritizismus und seine Bedeutung für die positive Wissenschaft..., op. cit., s. 46, 58-59.

23 A. Riehl, Beiträge zur Logik, O.R. Reisland, Leipzig 1912, s. 16-23. 
sądu analitycznego, o tyle sukcesja (Succession) jako następstwo rzeczy, zostaje uchwycona w formę sądu syntetycznego. Koegzystencja i sukcesja - jako współzależne - łączą się w stosunku korelacji poświadczając o wzajemnym powiązaniu sądów analitycznych i syntetycznych. Sądy analityczne są integralną częścią sądów syntetycznych i z tego tytułu nie sposób utworzyć sądu czysto-syntetycznego. Dlatego Riehl zakłada, że „nie ma sądów czysto-syntetycznych, gdyż każdy sąd syntetyczny domaga się sądu analitycznego. Przyjmuje, iż sąd może posiadać syntetyczne zastosowanie, niemniej jednak jego podstawy leżą zawsze w sądzie analitycznym. Każdy sąd syntetyczny potrzebuje sądu analitycznego.

Akt sądzenia jako moment wydawania sądu jest uznaniem i nadaniem treści przedstawienia charakteru rzeczywistego i prawdziwego; tymczasem sama treść przedstawienia jest niezależna od naszego pojmowania i naszej świadomości ${ }^{24}$. W przekonaniu Riehla w relacji podmiot-przedmiot, żaden z wyróżnionych członów nie ma cech absolutnych. Także w sytuacji „doświadczania istnienia czegoś mamy do czynienia tylko ze stanowiskiem relatywnym, ponieważ wszelkie czucie nosi w sobie cechę względności" ${ }^{25}$. Z kolei stanowisko absolutne jest wyrazem pojęcia krańcowego (Grenzbegriff jako pojęcie graniczne). Dlatego logiczne sądy pojęciowe, na przykład sąd: dusza istnieje, nawet gdyby posiadały wartość konieczna, asertoryczną lub apodyktyczną, stopniem pewności nie byłyby $\mathrm{w}$ stanie dorównać sądom zmysłowym ${ }^{26}$. Według Riehla jedynie determinowany czuciem osąd zmysłowy, pozwala poznającemu właściwie rozpoznać rzecz.

Znamienną cechą czucia (sentio), któremu poznawczo przygląda się Riehl jest także jego subiektywno-obiektywny charakter. Genezę tego empirycznego narzędzia poznania, będącego niejako kamieniem probierczym procesu poznania, wyznacza uświadamiające złączenie dwóch - wyróżnionych już wcześniej - czynników: czynnika podmiotowego i czynnika przedmiotowego. Czucie jest „bezpośrednim uświadomieniem sobie wzajemnego oddziaływania tych dwu czynników, $\mathrm{z}$ jednego z nich urabia się doświadczenie przedmiotowe, z drugiego zaś - doświadczenie podmiotowe" ${ }^{27}$. W takim ujęciu świadome czucie oscyluje w sferze pomiędzy, która nie ma znamion absolutnych; a to, do czego nas poznawczo prowadzi jest wynikiem oddziaływania dwóch

24 Por. J. Stepa, Neokantowskie próby realizmu..., op. cit., s. 30.

25 A. Riehl, Der philosophische Kritizismus und seine Bedeutung für die positive Wissenschaft, bd. 2, Verlag von Wilhelm Engelmann, Leipzig 1887, s. 43.

26 A. Riehl, Der philosophische Kritizismus und seine Bedeutung für positive Wissenschaft..., op. cit., s. 45-46. Por. J. Stepa, Neokantowskie próby realizmu..., op. cit., s. 29-34 .

27 A. Riehl, Der philosophische Kritizismus und seine Bedeutung für die positive Wissenschaft..., op. cit., s. 196. Zob. A. Noras, Historia neokantyzmu..., op. cit., s. 413. 
wyodrębnionych elementów, tj.: podmiotu i przedmiotu. W wyniku ich współdziałania, wyodrębnia się doświadczenie podmiotowe (subiektywizm) i doświadczenie przedmiotowe (obiektywizm).

Podejmując refleksję nad istotą czucia, Riehl wystosowuje argumenty przeciwko idealistom rozpatrującym czucie w kategoriach „nieświadomego tworu poznającej jaźni" 28 . Idealiści błędnie nazywają czucie snem, w którym nasze zmysły jedynie wydają nam się czynnym elementem procesu poznawania, jednak faktycznie są tylko zmysłowym złudzeniem. Wszystko to, co wyodrębnia się w ramach czucia stanowi wedle idealistów wytwór imaginacji i jako takie nie może być sposobnością do poznawania rzeczywistości ${ }^{29}$.

Riehl, odpierając ataki idealistów i broniąc poznawczej roli czucia, pozbawia je status elementu nieświadomego. Jednocześnie wskazuje granicę świadomości i uzależnia od czucia możliwość poznania świata rzeczywistego $\mathrm{w}$ ogóle. Jego zdaniem czucie odnosi się zarówno do czynnika podmiotowego, określając stan wewnętrzny poznającego, jak i czynnika przedmiotowego; czucie nie tylko zapoczątkowuje poznanie, ale przyjmuje także rolę tego, co dane, dynamiczne, konieczne i wskazujące na rzeczywistość; czucie jako empiryczne narzędzie poznania jest naturalnym znakiem rzeczy, możliwością poznania rzeczy świata zewnętrznego; jest tym, co odniesione do sfery przedmiotowej i jako takie, jest wyzbyte skrajnej subiektywności. Neokantysta komprymuje po raz kolejny wartość poznania umysłowego, nadając wyższą wartość czuciu i poznaniu zmysłowemu, które stanowią pierwszy czynnik możliwości poświadczenia o rzeczywistości zewnętrznej ${ }^{30}$.

Systematykę Riehlowskiego sposobu myślenia dopełnia przekonanie, w myśl którego twierdzenie o istnieniu świata realnego naznaczone jest piętnem - wychodzącej poza doświadczenie - spekulacji metafizycznej i odnosi się do sfery Ding an sich. Stepa ujmuje to w następującej formule: „Riehl sądzi, że twierdzenia filozoficzne w sprawie istnienia świata realnego noszą na sobie piętno spekulacji metafizycznej, gdyż wychodzą poza obręb doświadczenia. Jednak nie chodzi tu o rzeczywistość, daną nam w doświadczeniu, bo nikt nie zaprzecza jej istnieniu, lecz o rzecz samą w sobie, która poprzedza wszelkie doświadczenie i służy do jego uzasadnienia"31.

Zatem rzecz sama w sobie poprzedza i uzasadnia doświadczenie; jest również świadectwem obecności pierwiastka nie wpisującego się w strukturę tego, co jako dane na zewnątrz świadomego podmiotu poznającego, mieści się w granicach jego możliwości poznawczych. Sfera

28 J. Stepa, Neokantowskie próby realizmu a neotomizm..., op. cit., s. 35.

29 Ibidem, s. 35.

30 Ibidem, s. 38-40.

31 Ibidem, s. 40. 
spekulacji metafizycznej zakłada istnienie czegoś niezależnego od sfery Bewusstsein jako funkcji stosującej się do zjawisk rzeczy; świadomości jako funkcji poznawczego stosunku do przedmiotu istniejącego odrębne i niezależne od podmiotu; niezależnego przedmiotu, którego istnienie poznający musi przyjąć „,bo inaczej nie odnalazłby absolutnego punktu oparcia dla świadomości lub dla jej zjawisk"32.

W konsekwencji prowadzonego toku rozumowania, sytuacja poznającego jest analogiczna do sytuacji przedstawiciela nauk szczegółowych, stawiającego hipotezę i poszukującego w doświadczeniu jej potwierdzenia $^{33}$. Stepa, artykułując stanowisko Riehla, stwierdza: „Realistyczna teza ma tę zaletę, że najprostszą drogą prowadzi do rozwiązania problemu poznania. Można porównać ją do dobrze skonstruowanej hipotezy, która znajduje w doświadczeniu swe potwierdzenie" ${ }^{\prime 34}$.

Problem rzeczy samej w sobie, wzrastając do rangi fundamentalnego zagadnienia filozoficznej koncepcji Riehla, przywiązując zjawisko do realności, zakłada dwa otwarte pytania: pierwsze, ,,jak możemy utworzyć sobie przedstawienie rzeczywistości, różniącej się od nas?" Odpowiedź na postawione pytanie zawiera się $\mathrm{w}$ analizie problemu czucia. W czuciu uchwycony zostaje badany przedmiot, ukierunkowujący na pojęcie rzeczywistości; przedmiot poznania zostaje ujęty aktem czucia i w akcie czucia jest poznawczo opracowywany. Drugie pytanie, ,jak dochodzimy do pojęcia rzeczywistości przestrzennej w jej całej różnorodności?", Riehl wieńczy ripostą: zmysłami, wzrokiem i dotykiem ${ }^{35}$.

Świadectwo statusu świata rzeczywistego pieczętują dowody na istnienie tego świata. Deklarację jego istnienia Riehl opiera na dwóch zależnościach: pierwszą zależnością jest wykazanie filiacji świadomości czuciowej i czynnika działającego z zewnątrz. To fuzja czuciowego spostrzeżenia (elementu samodzielnego i bezpośredniego) z wyobrażeniem wytwórczym (elementem pochodnym). W złączeniu tym, świadomość wypełniają idealne pojęcia (kategorie intelektu, nieodkrywające istnienia, gdyż skupione wyłącznie na istocie rzeczy samej w sobie) oraz czuciowo-dążeniowy aspekt woli; każdy spostrzegany byt przedmiotu nie jest tu jedynie wytworem pojęciowym bądź wytworem naszej wyobraźni, lecz jest - złożonym z całości różnorodnych zmysłowych doznań -

32 Ibidem, s. 41. A. Riehl, Der philosophische Kritizismus und seine Bedeutung für positive Wissenschaft..., op. cit., s. 2-3, 18-21.

33 Zob. J. Stepa, Neokantowskie próby realizmu..., op. cit., s. 41.

34 Ibidem, s. 41. Zob. A. Riehl, Der philosophische Kritizismus und seine Bedeutung für positive Wissenschaft..., op. cit., s. 32, 64.

35 J. Stepa, Neokantowskie próby realizmu..., op. cit., s. 42-43. Zob. A. Noras, Historia neokantyzmu..., op. cit., s. 421. Por. A. Riehl, Der philosophische Kritizismus und seine Bedeutung für die positive Wissenschaft..., op. cit., s. 28, 196-198. 
przedmiotem rzeczywistym; jako taki jest rzeczywisty ${ }^{36}$. Także na tym etapie wartość poznania intelektualnego ulega deprecjacji. Dlatego Riehl pisze: „Nie mogę mówić, że myślę o bycie (Sein), gdyż byt nie stanowi części istotnej pojęcia. Byt może zostać odczuty, wyczuty, przeżyty, ale nie można go sobie wyobrazić lub przedstawić w pojęciu" ${ }^{\prime 37}$. Istnienie jest stosunkiem rzeczy i świadomości; stosunkiem domagającym się wyraźnego udziału zmysłów. Drugą zależnością jest zindywidualizowane czucie samozachowawczo-altruistycznych popędów naszej świadomości, zaspokajane spostrzeżeniem i refleksją lub uczuciem miłości, nienawiści i sympatii jako nieintelektualnymi odruchami czucia w naszej świadomości, ukierunkowanymi na podmioty poza nami ${ }^{38}$. Poznający odkrywa siebie jako istotę spostrzegająca, myśląca, odczuwająca, podejmującą działania i współistniejącą w emocjonalnych uczuciach sympatii, miłości i nienawiści, wraz z innymi podobnie poznającymi ${ }^{39}$.

Myśl skoncentrowana na istocie, nie odkrywa istnienia rzeczy. Rolę demaskatora istnienia przejmuje w systemie Riehla czucie jako realna platforma poznania. Czucie potwierdza istnienie rzeczy samej w sobie, jednak nie odkrywa jej istoty.

Sygnowane spostrzeżeniem czucie/doświadczenie łączy się z pojęciem. Pojęcie przekształca empiryczne spostrzeżenie. Na tej podstawie Riehl wskazuje na wyraźny związek aposteriorycznego spostrzeżenia z wysnutą z pojęć, aprioryczną myślą. Zaletą wiązania się myśli i spostrzeżeń jest możliwość przedstawienia sobie świata realnego. Riehl głosi, iż poznający kojarzy zwykle z spostrzeżeniem cały arsenał pojęć, które pozwalają mu przedstawić sobie świat realny. Wadą wnikania pojęć w spostrzeżenia jest jednak subiektywizm, który zniekształca poznającemu obraz rzeczywistości, ponieważ takiemu wplątanemu w spostrzeżenie pojęciu nie zostaje nadana cecha istniejącego indywidualnie przedmiotu realnego, lecz elementu zastępującego ten przedmiot w świadomości ${ }^{40}$. Riehl pisząc o świadomości eksponuje znaczenie procesualnej, niesubstancjalnej świadomości indywidualnej, która jest miejscem powstawania pojęć jako psychicznych tworów natury.

Świadomość ta, to siedlisko pojęć powstających w naturalnym procesie stawania się, wyłącznie w wyniku oddziaływania przedmiotów

36 Zob. A. Riehl, Der philosophische Kritizismus und seine Bedeutung für positive Wissenschaft..., op. cit., s. 158.

37 J. Stepa, Neokantowskie próby realizmu..., op. cit., s. 47. Zob. A. Riehl, Der philosophische Kritizismus und seine Bedeutung für positive Wissenschaft..., op. cit., s. 172.

38 Zob. J. Stepa, Neokantowskie próby realizmu..., s. 43-47.

39 K. Wieczorek, Spory o przedmiot poznania, Wydawnictwo Uniwersytetu Śląskiego, Katowice 2004, s. 201.

40 Zob. J. Stepa, Neokantowskie próby realizmu..., op. cit., s. 49. 
realnych. U jej podwalin leży, nieposiadająca statusu wartości ontologicznej, świadomość w ogóle ${ }^{41}$.

Riehl wiąże ze sobą zagadnienie procesualnej świadomości indywidualnej z problemem rozumienia bytu. Pojęcie bytu $\mathrm{w}$ jego filozofii nie ma charakteru względnego. Byt jest czymś istniejącym dla siebie, statycznym (w znaczeniu starożytnej szkoły elejskiej), absolutnym, wolnym i złożonym z istoty i istnienia. Pojęcie bytu, tak rozumiane, ,jest identyczne wszędzie, gdzie tylko znajduje zastosowanie i nie dopuszcza żadnego rozłamu, powiększenia lub uszczuplenia. To pojęcie odnosi się tylko do czegoś absolutnego, pozytywnego i niezłożonego"42.

Ponieważ nasze poznanie ogranicza się jednak do - rozpoznawalnej czuciem - sfery zjawiskowej, byt poza-zjawiskowy jest niepoznawalny. O ile według Riehla świat poznajemy zmysłowo, o tyle przedstawić możemy go sobie zarówno zmysłowo, jak i umysłowo. Neokantysta broni stanowiska, w myśl którego świat przedstawiamy sobie zmysłowo (to sytuacja, w której zmysły nadają rzeczy jedność w przestrzeni) bądź umysłowo (umysłowe ujęcie rzeczy pozwala utrzymać tym rzeczom jedność i stałość w czasie). O ile umysłowe, logiczne a priori jest łącznikiem wprowadzającym jedność w mozaice czucia, o tyle byt poza-zjawiskowy/niezjawiskowy, pozostaje pod względem poznawczym w swej istocie niedostępny. Możemy go rozpatrywać/przedstawiać sobie, ale nie poznawać zmysłowo lub umysłowo w odniesieniu do jedności naszej świadomości, ponieważ „rzeczy są stałymi grupami czuć, złączonych w jedną całość za pośrednictwem świadomości" ${ }^{43}$.

Do natury bytu należy także cecha jakościowego czucia, jednak zagadką pozostanie, twierdzi komentujący założenia filozofii Riehla Stepa, to „w jaki sposób zmysłowa podnieta zamienia się w czuciu na jakościowy przymiot"44. Niezaprzeczalnie wielość zjawisk poświadcza o bogatej i różnorodnej rzeczywistości świata realnego ${ }^{45}$. Każdy realny przedmiot dysponuje cechami jakościowo-ilościowymi. O cechach jakościowych przedmiotu świata realnego nie informuje jednak myślowy abstrakt, lecz zmysłowe czucie.

Wedle Riehla odbierając wrażenia świata zewnętrznego, zmysłowego układamy je czasowo i przestrzennie ${ }^{46}$. Formy czasu i przestrzeni mają wartość realną, wyodrębniają się z czuć i odnoszą się do przed-

41 Ibidem, s. 48-51.

42 A. Riehl, Realistische Grundzüge: Eine philosophische Abhandlung der Allgemeinen und nothwendigen Erfahrungsbegriffe, Leuschner \& Lubensky, Graz 1870, s. 10.

43 A. Riehl, Der philosophische Kritizismus und seine Bedeutung für positive Wissenschaft..., op. cit., s. 205.

44 J. Stepa, Neokantowskie próby realizmu..., op. cit., s. 57.

45 Por. Ibidem, s. 56-57.

46 A. Riehl, Der philosophische Kritizismus und seine Bedeutung für positive Wissenschaft..., op. cit., s. 80-184. 
miotowej rzeczywistości. Czas i przestrzeń Riehl nazywa empirycznymi pojęciami granicznymi (empirische Grenzbegriffe) o wartości realnej, odpowiadającymi formom świadomości i rzeczywistości ${ }^{47}$.

O ile Kant zakłada, że „przestrzeń jako forma jest warunkiem możliwości rzeczy, [o tyle Riehl uważa, że - A.M.] przestrzeń jest warunkiem poznania rzeczy"48. Rzecz poprzedza przestrzeń i czas. Rzecz dana w doświadczeniu jest zjawiskiem bytu. Zjawiska powstają na skutek współpracy narządów zmysłowych: zmysłów, które nadają zjawiskom cech jakościowych i przedmiotów, za sprawą których zjawiska zyskują swoją przedmiotowość. Powtórzyć należy, iż przedmiotowe zjawisko, materialny fakt, ma w filozofii Riehla większą wartość niż myślowy korelat poznającego podmiotu rozpoznającego fizyczno-psychiczne zjawiska.

W filozofii Riehla materialny fakt oraz psychiczne zjawisko są tego samego gatunku. O ile jednak materia implikuje przedmiot, o tyle psychika zawsze pociąga za sobą podmiotowość. Podmiotowa świadomość jest prematerialnym i niematerialnym pierwiastkiem psychicznym sił oddziałujących na materię. Ponadto każde zjawisko posiada znamiona fizyczne (zewnętrzne) oraz psychiczne (wewnętrzne) i jako takie łączy świat przyrody/przyrodę z myśleniem.

W konsekwencji Riehl wyzbywa się psycho-fizycznego dualizmu, wiążąc w zjawisku to, co fizyczne z tym, co psychiczne, sprowadzając psychikę do jakościowego elementu fizyczności i nazywa swój system monizmem krytycznym lub monizmem filozoficznym. Monizmem utożsamiającym element psychiczny z jakością elementu fizycznego. Taka monistyczna rzeczywistość Riehla jest zgodnością praw przyrody i praw myślenia; spójnością praw przyrody i praw myślenia; harmonią sfer: sfery przyrodniczej i sfery myślenia; harmonia ta jest celem i nagrodą każdego badania ${ }^{49}$.

Problematyczność stanowiska autora Beiträge zur Logik, zawiera się jednak w pytaniu: „w jaki sposób ta sama rzecz może występować $\mathrm{w}$ dwojakiej formie zjawiskowej? W systemie realizmu krytycznego Riehla, materialny substrat zostaje przedłożony nad duchowe czynności $^{50}$. O rzeczy samej w sobie człowiek wie tylko, że istnieje; z racji swojej struktury jest ona jednak dla człowieka niepoznawalna. Zdolność jej poznania przysługuje wyłącznie istocie o innej niż człowiecza organiza$\mathrm{cji}^{51}$.

47 Zob. A. Noras, Historia neokantyzmu..., op. cit., s. 424.

48 J. Stepa, Neokantowskie próby realizmu..., op. cit., s. 61.

49 Ibidem, s. 65.

50 Ibidem, s. 64-66. Zob. A. Riehl, Zur Einführung in die Philosophie der Gegenwart..., op. cit., s. 52-85, 128-168.

51 J. Stepa, Neokantowskie próby realizmu..., op. cit., s. 67. 
Ewaluację systemu Riehla, Stepa rozpoczyna ekspertyzą stosunku myśli Riehla do filozoficznego zamysłu Kanta. Riehl uznaje, iż Kant popełnia błąd próby nieempirycznego rozwiązania stawianych problemów. A mianowicie: pytając o sądy syntetyczne a priori, Kant chce spoglądając z perspektywy racjonalizmu, skupiając uwagę wyłącznie na formie i zapominając o treści doświadczenia - podważyć fundamenty metafizyki. Tymczasem cytujący Riehla, lwowski profesor filozofii pisze, iż współcześnie należy wyróżnioną kwestię teoriopoznawczą przedstawić alias, zapytując: ,jjak i w jakich warunkach poznanie nasze może być zrozumiałe? Główny zaś nacisk powinno się położyć na wyjaśnienie kwestii ujętej w formule pytania zamkniętego: czy możliwe jest poznanie empiryczne" 52 .

Dlatego Riehl skupia uwagę na niesubiektywnym świecie realnym. Uważa, że „istnienie świata zewnętrznego przedstawia się nam, nie jako subiektywna wiara lub jako wynik naszego rozumowania, ale jako bezpośrednia wiedza, która wyprzedza wszystko, co nosi cechę pośredniości"53, a czucie wciśnięte w czas i przestrzeń, staje się pierwszym czynnikiem pozwalającym dotrzeć do przedmiotu poznania.

Według osądu tarnowskiego biskupa w trakcie prowadzenia analiz, Riehl popełnia błąd zatrzymując się w połowie drogi. Brakuje mu konsekwentnych rozstrzygnięć, które poświadczyłyby o bezpośredniości realizmu. Neokantysta pozostaje czcicielem zmysłowego czucia i sensualistycznej teorii poznania ${ }^{54}$.

Mimo wad konstrukcyjnych realizmu krytycznego, Riehl dokonuje próby rozwiązania realistycznego problemu poznania. Rozwiązanie to stałoby się możliwe "gdyby tylko rozciągnął bezpośredniość poznania także na intelekt i nie zatrzymywał jego mocy poznawczej na samych pojęciach, lecz pozwolił mu sięgnąć poprzez pojęcia do rzeczy, zbliżając się do zamierzonego celu" ${ }^{\prime 55}$.

Tymczasem pojęcia w nie-intelektualnym realizmie zapośredniczonym austriackiego neokantysty są medium quod - intelekt nie odgrywa W zaaranżowanym procesie poznania większej roli. W systemie Riehla pojęcia zwodzą. Są one jak „szkła przez które spoglądamy na świat" ${ }^{26}$. W konsekwencji Riehl zapisze się w historii filozofii jako ten, który nawraca myśl Kanta na empiryzm ${ }^{57}$.

52 Ibidem, s. 67.

53 Zob. A. Riehl, Der philosophische Kritizismus und seine Bedeutung für positive Wissenschaft...,op. cit., s. 186.

54 J. Stepa, Neokantowskie próby realizmu..., op. cit., s. 69-73.

55 Ibidem, s. 78.

56 Ibidem, s. 78.

57 Zob. ibidem, s. 73-79. 
Chociaż stanowisko Riehla jest wybitnie aintelektualne, bo ignorujące sferę myśli w poznaniu, staje się niebłahą i niepospolitą próbą realistycznej wykładni krytycyzmu Kantowskiego. Ostatecznie Alois Riehl stwarza taką jego postać, która wykracza poza klasykę nowożytnego rozumienia krytycyzmu ${ }^{58}$. W związku z tym słuszna staje się teza, której autorem jest Carl Siegel uważający, że filozoficzny program Riehla nie mieści się już w Liebmannowskim postulacie powrotu do Kanta, lecz dla swej realizacji wymaga nowego hasła. Brzmi ono: „naprzód od Kanta”59.

\section{Bibliografia}

Liebmann O., Kant und die Epigonen, Stuttgart C. Schober, Stuttgart 1865.

Kant I., Krytyka czystego rozumu, przeł. R. Ingarden, Kęty 2001.

Kant I., O postępach metafizyki. tłum. A. Banaszkiewicz, Wydawnictwo słowo/obraz terytoria, Gdańsk 2007.

Moog W., Die deutsche Philosophie des 20. Jahrhunderts in ihren Grundproblemen, Verlag von Ferdinand Enke, Stuttgart 1922.

Noras A., Historia neokantyzmu, Wydawnictwo Uniwersytetu Śląskiego, Katowice 2012.

Nowak A., Słownik biograficzny kapłanów diecezji tarnowskiej 1786-1985, t. 1, Biskupi i kanonicy, Wydawnictwo Diecezji Tarnowskiej, Tarnów 1999.

Riehl A., Beiträge zur Logik, O.R. Reisland, Leipzig 1912.

Riehl A., Der Philosophische Kritizismus. Geschichte und System. Geschichte des Philosophischen Kritizismus, Bd. 1, Verlag von Wilhelm Engelmann, Leipzig 1908.

Riehl A., Der philosophische Kritizismus und seine Bedeutung für positive Wissenschaft, bd. 2, Verlag von Wilhelm Engelmann, Leipzig 1887.

Riehl A., Realistische Grundzüge: Eine philosophische Abhandlung der Allgemeinen und nothwendigen Erfahrungsbegriffe, Leuschner \& Lubensky, Graz 1870.

Riehl A., Über Begriff und Form der Philosophie. Eine allgemeine Einleitung in das Studium der Philosophie, Duncker, Berlin 1872.

Riehl A., Über wissenschaftliche und nichtwissenschaftliche Philosophie, w: Philosophische Studien aus vier Jahrzehnten, Verlag von Wilhelm Engelmann, Leipzig 1925.

Riehl A., Zur Einführung in die Philosophie der Gegenwart. Acht Vorträge, B.G. Teubuer, Leipzig 1908.

Riehl A., Zur Einführung in die Philosophie der Gegenwart. Acht Vorträge, B.G. Teubner, Leipzig 1903.

58 Zob. ibidem, s. 79-83.

59 C. Siegel, Alois Riehl. Ein Beitrag zur Geschichte des Neukantianismus, Leuschner \& Lubensky, Graz 1932, s. 10. 
Siegel C., Alois Riehl. Ein Beitrag zur Geschichte des Neukantianismus, Leuschner \& Lubensky, Graz 1932.

Stepa J., Neokantowskie próby realizmu a neotomizm, Bibljoteka Religijna, Lwów 1927.

Trochimska-Kubacka B., Neokantyzm, Wydawnictwo Uniwersytetu Śląskiego, Wrocław 1997

Überweg F., Grundriss der Geschichte der Philosophie vom Beginn des XX Jahrhunderts bis auf die Gegenwart, hrsg. V. K. Österreich, Berlin 1916.

Wieczorek K., Spory o przedmiot poznania, Wydawnictwo Uniwersytetu Śląskiego, Katowice 2004.

\section{Realistyczny neokantyzm Aloisa Riehla w interpretacji Jana Stepy}

\section{Słowa kluczowe}

Neokantyzm; realizm; monizm krytyczny; sentio; cogito; świadomość; sąd zmysłowy; sąd logiczny; Riehl, Stepa

W artykule opisuję wykładnię realizmu neokantysty Aloisa Riehla zaproponowaną przez Jana Stepę. Tekst ma charakter wyłącznie historyczno-filozoficzny i prezentuje sposób odczytania monizmu krytycznego (filozoficznego) Riehla przez polskiego filozofa reprezentującego chrześcijańską szkołę filozofii lwowskiej. Szczególny akcent pada w artykule na sposób rozumienia świadomości jako świadomości czucia (sentio), zmysłowego sądu, czasu i przestrzeni, a także rzeczy danej w doświadczeniu jako zjawiska bytu.

\section{Alois Riehl's realistic Neo-Kantinism on interpretation of Jan Stepa}

\section{Keywords}

Neo-Kantianism; realism; critical monism; sentio; cogito; consciousness; sensorial reason; logical reason; Riehl; Stepa

In this paper I focus interpretation of Alois Riehl's realism in Neo-Kantianism proposed by Jan Stepa. The text has a character exclusively historical-philosophical and presents manner of reading Riehl's critical monism (philosophical monism) by Polish philosopher representing the Christian school of Lvov philosophy. The article the special accent puts by the manner of understanding conand also the given thing in the experience sciousness as feeling consciousnesses (sentio), sensorial reason, time and space, as occurrences of the being. 